\title{
Camel Milk as Adjuvant to Treat Alloxan Diabetes: Effect of Heat Treatment on this Property
}

Amel Sboui ${ }^{1,2 *}$, Touhami Khorchani' ${ }^{1}$, Mongi Djegham ${ }^{2}$, Aroua Agrebi $^{2,3}$, Amel Dalleli $^{2}$ and Omrane Belhadj ${ }^{3}$

${ }^{1}$ Livestock and Wildlife Laboratory, Arid Land Institute, route Edjorf, Elfgè, 4119, Medenine, Tunisia

${ }^{2}$ Physiology and Therapeutic Laboratory, Tunisian Veterinary School of medicine, 2020, Sidi Thabet, Tunisia

${ }^{3}$ Biochemistry and Techno biology Laboratory, Department of Biology, College of Sciences, Tunis El-Manar, Tunisia

\begin{abstract}
Camel milk is recognized by nomads for its therapeutic effect to treat several diseases especially diabetes. This study was conducted to evaluate the effect of raw, pasteurized and boiled camel milk on Alloxan-induced diabetic dogs.

Firstly, three groups of dogs were used: group 1 and group 2 composed each of 4 diabetic dogs and receiving respectively $250 \mathrm{ml}$ of raw camel milk/ dog/ day or $250 \mathrm{ml}$ of raw cow milk/ dog/ day. Group 3 consisted of 4 healthy dogs getting raw camel milk were used as control. Secondly, we tested the effect of heat treatment on the anti-diabetic property of camel milk. Two other groups composed of 4 diabetics dogs each and treated with $250 \mathrm{ml}$ of pasteurized camel milk/ dog/ day (group 4) or with $250 \mathrm{ml}$ of boiled camel milk/ dog/ day (group 5).
\end{abstract}

By the end of milk treatment, group1 showed a significant decrease in blood glucose (from $10.16 \pm 1.16$ to $5.22 \pm$ $1.06 \mathrm{mmol} / \mathrm{l}$ ), in cholesterol $(6.94 \pm 0.06$ to $5.04 \pm 0.8 \mathrm{mmol} / \mathrm{l}$ ) and in total proteins levels (from $75.31 \pm 4.68$ to 65.44 $\pm 0.76 \mathrm{~g} / \mathrm{l})$.

A same result was revealed in animals getting pasteurized camel milk: blood glucose, in cholesterol and total protein concentrations. After 3 weeks of treatment with pasteurized milk, all these parameters didn't show any significant differences when compared with group 1 (treated with raw camel milk). Whereas, the animals receiving boiled camel milk (group 5) demonstrated high blood glucose $(10.5 \pm 0.52 \mathrm{mmol} / \mathrm{l})$, total proteins $(72.03 \pm 6.49 \mathrm{~g} / \mathrm{l})$ and cholesterol levels $(7.02 \pm 0.44 \mathrm{mmol} / \mathrm{l})$

The investigation during this research was not only the effectiveness of "raw or pasteurized" camel milk to treat diabetic dogs but especially the curative effect of this product shown after stopping to drink milk. However this therapeutic effect was disappearing using boiled camel milk to treat diabetic dogs.

Keywords: Camel milk; Heat treatment; Diabetes; Dogs; Alloxan

\section{Introduction}

Diabetes mellitus is one of the most common endocrine diseases in dogs. Type I of diabetes is caused by the lack of insulin and results from the destruction of the insulin-producing beta cells in the pancreas [1].

This metabolic disorder can be caused chemically using many components such as Alloxan and streptozotocine. Alloxanic diabetes is caused by the selective pancreatic beta cell toxicity of this composite $[2,3]$. Several species were sensitive to Alloxan toxicity such as rats, rabbit and dogs $[4,5]$.

The pharmaceutical drugs used in diabetic therapy are either too expensive or have undesirable side-effects or contraindications [6]. Therefore, the search for more effective and safer hypoglycaemic agents has continued to be an area of active research $[7,8]$. In arid regions, camel milk is described for its usefulness to treat diabetes mellitus. In the same way, an Indian study has reported a hypoglycaemic effect of camel milk on diabetic rats [9].

This research was conducted to verify the effect of camel milk in diabetic dogs in comparison to cow milk and to follow the efficiency of this effect after heat treatment of milk (pasteurized and boiled camel milk).

Alloxan-diabetic dog was used because it is a model of partial insulin deficiency and insulin resistance while simulating postprandial conditions in diabetic patients [10].

\section{Materials and Methods}

\section{Animals and diets}

Twenty clinically normal adult mixed-breed dogs were prepared for this experiment. Their body weight ranged from 12 to $16 \mathrm{~kg}$ initially.

These dogs were housed individually in the Tunisian Veterinary Medicine School, Sidi Thabet. Animals were fed once daily with 350$400 \mathrm{~g}$ of commercial dry food ( $23 \%$ protein, $6 \%$ fat, $33 \%$ carbohydrates, $4 \%$ crude fiber and $3000 \mathrm{kcal} / \mathrm{kg}$ as energetic value; (DOGSY) from Tunisian Animal Nutrition Society) and $200 \mathrm{~g}$ of beef.

This food was given to all dogs daily in the morning after drinking milk. All animal were controlled when drinking milk to be sure that all the quantity given was consumed by the dogs. Water was available ad libitum for dogs throughout the duration of the experiment.

\section{Experimental design}

Each test was divided into two periods, the first 5 weeks in which

*Corresponding author: Amel Sboui, Livestock and Wildlife Laboratory, Arid Land Institute, route Edjorf, Elfgè 4119, Medenine, Tunisia, Tel: +216.23.385.201; E-mail: amelsb6@yahoo.fr

Received January 21, 2012; Accepted May 29, 2012; Published June 03, 2012

Citation: Sboui A, Khorchani T, Djegham M, Agrebi A, Dalleli A, et al. (2012) Came Milk as Adjuvant to Treat Alloxan Diabetes: Effect of Heat Treatment on this Property. J Diabetes Metab 3:190. doi:10.4172/2155-6156.1000190

Copyright: $\odot 2012$ Sboui A, et al. This is an open-access article distributed unde the terms of the Creative Commons Attribution License, which permits unrestricted use, distribution, and reproduction in any medium, provided the original author and source are credited. 
the animals were treated with milk, and weeks 6 and 7 to follow the variations of all analyzed characteristics after stopping the milk treatment. All essays were achieved in the same period and under the same conditions.

\section{Induction of diabetes}

After overnight fasting, the dogs were injected by an intravenous administration of $65 \mathrm{mg}$ of alloxan monohydrate (Sigma, Aldrich; Germany)/ $\mathrm{kg}$ of body weight $[3,11]$. The alloxan solution was prepared by dissolving it in normal saline at a concentration of $100 \mathrm{mg} / \mathrm{ml}$ and injected freshly after filtration. Seven days later, these animals showed a diabetic state characterized by a high fasting blood glucose $(>10$ $\mathrm{mmol} / \mathrm{l}$ ) and presence of glucose level in urine $(+++)$.

\section{Milk samples}

Camel milk used during this study was obtained from a camel herd (camelus dromedarius) belonging the Arid Land Institute (Medenine, Tunisia) and cow milk was given from a Tunisian breed of cow housed in the Veterinary School of Medicine, Sidi Thabet, Tunisia.

Raw camel milk was delivered freshly, without any dilution, to the animals. Pasteurized milk was treated at $63^{\circ} \mathrm{C}$ during 30 minutes, cooled at room temperature. Boiled milk was treated at $100^{\circ} \mathrm{C}$ during 3 minutes after boiling and distributed after cooling at room temperature.

For all milk samples, $\mathrm{pH}$ and acidity were checked to monitor the freshness of milk. The gross composition of all types of milk was determined (fat, total proteins and total solids). Fat content was measured using the neusol method [12], and the total proteins concentration was determined by the Kjheldahl method using a nitrogen conversion factor of 6.36 [13]. Total solids were evaluated after drying at $105^{\circ} \mathrm{C}$ until a steady weight was achieved [13].

\section{Test 1: Effect of raw camel milk on diabetic dogs}

Twelve adult dogs were divided in 3 groups each one containing four dogs. Group 1 was composed of diabetic dogs receiving raw camel milk, group 2 consisted of diabetic dogs getting raw cow milk and healthy dogs (group 3) drinking camel milk and used as control. Two hundred and fifty $\mathrm{ml}$ of milk was given daily, fasting, in the morning for each animal during 5 weeks followed by two weeks (without milk treatment) in which all parameters were analyzed.

\section{Intravenous glucose tolerance test: IGTT}

An Intravenous Glucose Tolerance Test (IGTT) assay was performed aiming to verify the glycemic state (diabetic or not) of the animals. This test was performed on all animals (diabetic or no) after the end of the first test. Glucose was injected after an overnight fasting, by intravenous administration of $0.5 \mathrm{~g}$ of glucose $/ \mathrm{kg}$ of body weight. Blood sample was drawn at each 30 min during $3 \mathrm{~h}$.

Test 2: Effect of heat treatment on the anti-diabetic effect of camel milk

Two other groups composed by four diabetic dogs (groups 4 and 5 ) were the subject of this experiment step and were given respectively $250 \mathrm{ml}$ of pasteurized camel milk (group 4) and $250 \mathrm{ml}$ of boiled camel milk (group 5). Milk was given to each animal daily during five weeks.

\section{Urine analysis}

During the first week after injection of alloxan, urine samples were subjected to analyze glucosuria, proteins and ketones. These analyses were performed using Bayer Strips (Bayer Diagnostics Mfg, Bridgen, UK) for Urine analysis.

\section{Blood samples}

Blood samples were drawn from the radial vein with Vacutainer system; these samples were divided into two tubes: one for glycemic assay (enclose oxalate fluorure), other for cholesterol, TG and total proteins assays. Blood samples were realized 2 times per week during the milk treatment (5 weeks) and two weeks (weeks 6 and 7) after the end of the experiment.

Blood glucose concentrations was measured by a glucose oxidase method (Biomaghreb ${ }^{\circledR}$, Tunis, Tunisia) using a spectrophotometer CECIL (CE 2041) at $505 \mathrm{~nm}$.

Cholesterol and Triglycerides concentrations were determined by enzymatic methods (Biomaghreb ${ }^{\circledR}$ ) using spectrophotometer CECIL (CE 2041) at $505 \mathrm{~nm}$. Total proteins concentrations were analyzed at $546 \mathrm{~nm}$.

\section{Statistical analysis}

The data were expressed as the mean \pm SEM and represented the average values for the animals in the same group. These data were subjected to statistical analysis, using SAS computer software (SAS institute, 1998), to be compared between and within the experimental groups.

This test combines ANOVA with comparison of differences between the means of the treatments at the significance level of $\mathrm{p}<0.05$.

\section{Results}

\section{Effect of the heat treatment on the gross composition of milk samples}

Milk analysis: The $\mathrm{pH}$ and acidity of the camel milk provided to the animals were respectively $6.41 \pm 0.18$ and $16.87 \pm 1.035^{\circ}$ Dornic. These characteristics for the cow milk were as follows: $6.61 \pm 0.24$ for $\mathrm{pH}$ and $17.12 \pm 0.64^{\circ}$ Dornic.

Camel milk used during this study was rich in total protein $(34.15$ $\pm 3.11 \mathrm{~g} / \mathrm{l})$ and in total solids $(119.43 \pm 1.84 \mathrm{~g} / \mathrm{l})$ compared with bovine milk $(30.5 \pm 1.95 \mathrm{~g} / \mathrm{l}$ for total proteins and $104.88 \pm 4.39 \mathrm{~g} / \mathrm{l}$ for total solid amounts). There was no significant difference in fat among the camel and cow milk used $(34.5 \pm 3.1 \mathrm{~g} / \mathrm{l}$ in camel milk and $32.5 \pm 2.12$ $\mathrm{g} / \mathrm{l}$ in bovine milk).

The effect of heat treatment on camel milk composition was revealed only on boiled camel milk which showed a significant decrease on fat concentration (from $37.5 \pm 5$ to $33.37 \pm 5.18 \mathrm{~g} / \mathrm{l}, \mathrm{p}=0.002$ ).

\section{Effect of raw camel milk compared to cow milk on diabetic dogs}

After 5 weeks of treatment with raw camel milk, a significant decrease on blood glucose levels was noted; from $10.16 \pm 1.16$ to 5.22 $\pm 1.06 \mathrm{mmol} / \mathrm{l}(\mathrm{p}=0.03)$ in group 1 (Figure 1$)$. This decrease was statistically significant since week 3 and showed a non significant difference in comparison with the healthy group in which Blood glucose concentrations was about $5.17 \pm 0.25 \mathrm{mmol} / \mathrm{l}$. The dogs getting cow milk showed a steady high blood glucose level $(9.29 \pm 0.9 \mathrm{mmol} / \mathrm{l})$, glucosuria $(+++)$ and proteinuria $(++)$ (Figure 1$)$.

\section{Intravenous Glucose Tolerance Test (IGTT)}

The results of this test are represented in figure 2; the difference was mostly observed among the three treatments, especially among the dogs treated with raw cow milk and the two other groups. The 


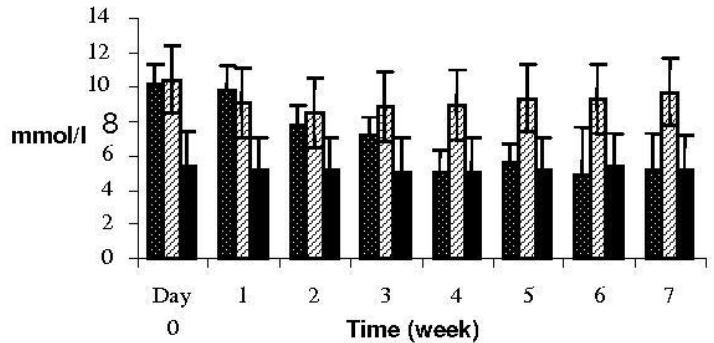

眼 Group 1

Group 2

- Group 3

Figure 1: Group 1: Diabetic dogs treated with $250 \mathrm{ml}$ of raw camel milk/ dog/ day. Group 2: Diabetic dogs treated with $250 \mathrm{ml}$ of raw cow milk/ dog/day. Group 3: Healthy dogs used as control. Weeks 1 to 5 : During the treatment with milk. Weeks 6 and 7: After stopping drinking milk.

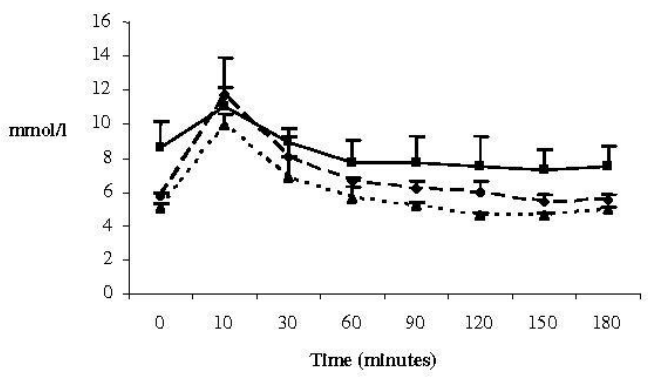

$\begin{array}{ll}- & \text { Group } 1 \\ \cdots-- & \text { Group } 2\end{array}$

Group 3

Figure 2 : Group 1: Diabetic dogs treated with raw camel milk. Group 2: Diabetic dogs treated with raw cow milk. Group 3: Healthy group.

diabetic dogs which were treated with cow milk (group 2) showed a steady diabetic state that was confirmed before injection of glucose by a high blood glucose level $(8.61 \pm 0.22 \mathrm{mmol} / \mathrm{l})$ and a stability of high blood glucose level during this test $(7.78 \pm 0.55 \mathrm{mmol} / \mathrm{l})$. However, in group 1 - treated with camel milk-blood glucose levels illustrated a large decrease after $60 \mathrm{~min}$ (from $9.07 \pm 0.53 \mathrm{mmol} / \mathrm{l}$ (at $10 \mathrm{~min}$ ) to $6.49 \pm 0.9 \mathrm{mmol} / \mathrm{l}$ ) and a steadiness of this parameter within the normal range ( $5.5 \pm 0.94 \mathrm{mmol} / \mathrm{l}$ ) (Figure 2); variations of blood glucose levels during the IGTT test revealed a nonsignificant difference ( $p>0.05)$ between the animals drinking camel milk (group 1) and the healthy group (group 3 ).

\section{TG, cholesterol and total proteins variations}

Only TG concentrations were not influenced by the diabetic state in dogs and the treatment with camel milk (Table 1).

Since the third week, dogs from group 1 showed a significant decrease on cholesterol and total proteins concentrations $(\mathrm{p}<0.05)$ respectively from $6.94 \pm 0.06$ to $5.42 \pm 0.48 \mathrm{mmol} / \mathrm{l}$ and from $77.31 \pm$ 2.68 to $68.71 \pm 1.8 \mathrm{~g} / \mathrm{l}$.

Dogs from group 2 showed a stable diabetic state illustrated by high cholesterol $(6.85 \pm 0.93 \mathrm{mmol} / \mathrm{l})$ and total proteins concentrations $(82.83 \pm 3.83 \mathrm{~g} / \mathrm{l})$

\section{Effect of heat treatment on the anti-diabetic effect of camel} milk

Glycemic balance: During the second test, group 4 (treated with pasteurized camel milk) showed a significant decrease on blood glucose levels from $9.85 \pm 1.98$ to $6.3 \pm 1.02 \mathrm{mmol} / \mathrm{l} ; \mathrm{p}<0.05$ (Figure 3). Statistical analysis revealed no significant difference between groups 1 and 4.

For these groups ( 1 and 4 ) receiving respectively raw and pasteurized camel milk, the improvement on glycemic balance was shown also after stopping to drink camel milk and illustrated by a normal range of blood glucose concentrations (5.64 $\pm 1.3 \mathrm{mmol} / \mathrm{l}$ ) (Figure 3).

In this time group 5 (getting boiled camel milk) illustrated a steady diabetic state approved by high blood glucose concentrations $(10.25 \pm 0.68 \mathrm{mmol} / \mathrm{l}$ in average), glucosuria $(+++)$, proteinuria $(++)$ and ketones $(++)$. Statistical analysis showed a significant difference between group 5 and the tow other groups (groups 1 and 4).

TG, cholesterol and total proteins variations: Only TG concentrations did not show any variations for all treatments during the experiment (Table 2). During the treatment with pasteurized camel milk, analyzed parameter illustrated a decrease on cholesterol concentrations (from $7.25 \pm 1.11$ to $5.18 \pm 0.97 \mathrm{mmol} / \mathrm{l}$ ) and on total proteins concentrations (from $74.84 \pm 5.45$ to $66.03 \pm 3.36 \mathrm{~g} / \mathrm{l}$ ). Weekly variations of these parameters revealed a statistically significant decrease on cholesterol concentrations (from $7.25 \pm 1.11$ to $4.78 \pm 1.6$

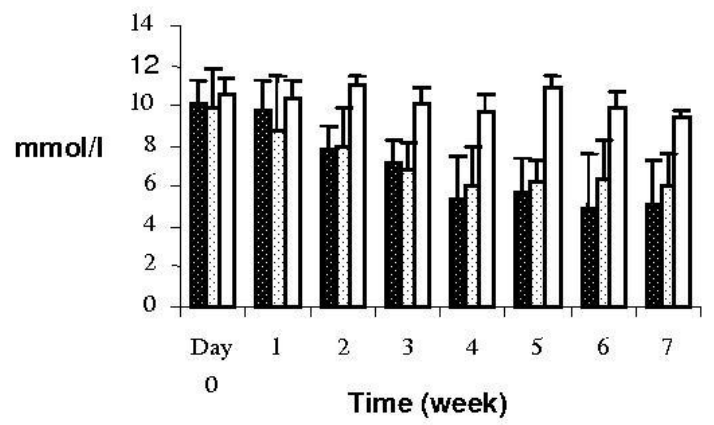

\section{㽢 Group 1 \\ $\square$ Group 4 \\ 口 Group 5}

Weeks 1 to 5: During the treatment with milk

Weeks 6 and 7: After stopping drinking milk

Figure 3 : Group 1: Diabetic dogs receiving $250 \mathrm{ml}$ raw camel milk / dog/ day. Group 4: Diabetic dogs getting $250 \mathrm{ml}$ pasteurized camel milk / dog/ day. Group 5: Diabetic dogs receiving $250 \mathrm{ml}$ boiled camel milk / dog/ day. Weeks 1 to 5 : During the treatment with milk. Weeks 6 and 7: After stopping drinking milk. 


\begin{tabular}{|c|c|c|c|c|c|c|c|c|}
\hline \multicolumn{3}{|c|}{ Total proteins (g/l) } & \multicolumn{3}{|c|}{ Cholesterol (mmol/l) } & \multicolumn{3}{|c|}{ TG (mmol/l) } \\
\hline Group 1 & Group 2 & Group 3 & Group 1 & Group 2 & Group 3 & Group 1 & Group 2 & Group 3 \\
\hline $75.31^{\mathrm{a}} \pm 4.68$ & $80.36^{a} \pm 0.9$ & $8.48^{b} \pm 1.11$ & $6.94^{\mathrm{a}} \pm 0.06$ & $6.99^{\mathrm{a}} \pm 0.58$ & $4.17^{\mathrm{b}} \pm 1.2$ & $1.11 \pm 0.15$ & $1.03 \pm 0.17$ & $0.95 \pm 0.27$ \\
\hline $71.26^{\mathrm{a}} \pm 2.46$ & $77.35^{\mathrm{a}} \pm 5.5$ & $68.8^{\mathrm{b}} \pm 1.25$ & $6.96^{\mathrm{a}} \pm 0.43$ & $6.64^{\mathrm{a}} \pm 1.31$ & $3.98^{\mathrm{b}} \pm 0.25$ & $0.93 \pm 0.15$ & $1.29 \pm 0.19$ & $0.64 \pm 0.22$ \\
\hline $74.21^{\mathrm{a}} \pm 6.39$ & $79.87^{\mathrm{a}} \pm 4.13$ & $67.06^{b} \pm 2.27$ & $6.41^{\mathrm{a}} \pm 0.51$ & $6.81^{\mathrm{a}} \pm 0.21$ & $4.71^{\mathrm{b}} \pm 0.07$ & $0.65 \pm 0.01$ & $1.27 \pm 0.63$ & $0.66 \pm 0.15$ \\
\hline $69.71^{\mathrm{b}} \pm 2.8$ & $84.79^{\mathrm{a}} \pm 4.47$ & $67.75^{\mathrm{b}} \pm 2.17$ & $5.42^{\mathrm{b}} \pm 0.48$ & $6.78^{\mathrm{a}} \pm 1.95$ & $4.82^{\mathrm{b}} \pm 0.64$ & $0.96 \pm 0.31$ & $1.32 \pm 0.07$ & $0.74 \pm 0.15$ \\
\hline $67.08^{b} \pm 0.15$ & $83.28^{a} \pm 2.77$ & $64.82^{\mathrm{b}} \pm 4.11$ & $5.11^{\mathrm{b}} \pm 0.72$ & $6.83^{a} \pm 0.58$ & $4.21^{\mathrm{b}} \pm 0.46$ & $0.92 \pm 0.28$ & $1.17 \pm 0.25$ & $0.92 \pm 0.83$ \\
\hline $65.44^{\mathrm{b}} \pm 0.76$ & $85.36^{a} \pm 1.21$ & $65.45^{\mathrm{b}} \pm 1.03$ & $5.04^{b} \pm 0.8$ & $7.08^{\mathrm{a}} \pm 0.98$ & $4.08^{b} \pm 0.33$ & $1.04 \pm 0.68$ & $1.14 \pm 0.33$ & $0.9 \pm 0.32$ \\
\hline $64.19^{b} \pm 1.79$ & $82.92^{\mathrm{a}} \pm 2.35$ & $64.63^{\mathrm{b}} \pm 3.2$ & $4.66^{\mathrm{b}} \pm 1.17$ & $6.71^{\mathrm{a}} \pm 1.23$ & $4.65^{\mathrm{b}} \pm 0.56$ & $0.8 \pm 0.11$ & $1.21 \pm 0.52$ & $1.01 \pm 0.38$ \\
\hline $65.2^{\mathrm{b}} \pm 1.58$ & $83.25^{\mathrm{a}} \pm 3.14$ & $65.02^{b} \pm 1.04$ & $4.86^{\mathrm{b}} \pm 0.79$ & $6.83^{a} \pm 0.42$ & $4.51^{\mathrm{b}} \pm 0.36$ & $1.04 \pm 0.08$ & $1.13 \pm 0.64$ & $0.98 \pm 0.62$ \\
\hline
\end{tabular}

For each analyzed characteristic: Means with the same letter -in each line and column- are not significantly different: $p \geq 0.05$

Weeks 6 and 7: After stopping drinking milk

Group 1: Diabetic dogs receiving $250 \mathrm{ml}$ raw camel milk / dog/ day

Group 2: Diabetic dogs getting $250 \mathrm{ml}$ raw cow milk / dog/ day

Group 3: Healthy dogs receiving $250 \mathrm{ml}$ raw camel milk / dog/ day

Table 1: Weekly variations of total proteins, cholesterol and TG concentrations on groups 1, 2 and 3 during the first test.

\begin{tabular}{|c|c|c|c|c|c|c|c|c|c|}
\hline & \multicolumn{3}{|c|}{ Total proteins (g/l) } & \multicolumn{3}{|c|}{ Cholesterol (mmol/l) } & \multicolumn{3}{|c|}{ TG (mmol/l) } \\
\hline & Group 1 & Group 4 & Group 5 & Group 1 & Group 4 & Group 5 & Group 1 & Group 4 & Group 5 \\
\hline Day 0 & $75.31^{\mathrm{a}} \pm 4.68$ & $74.84^{\mathrm{a}} \pm 5.45$ & $76.59^{\mathrm{a}} \pm 7.21$ & $6.94^{\mathrm{a}} \pm 0.06$ & $7.25^{\mathrm{a}} \pm 1,11$ & $7.33^{\mathrm{a}} \pm 0.22$ & $1.11 \pm 0.15$ & $0.94 \pm 0.22$ & $1.13 \pm 0.22$ \\
\hline Week 1 & $71.26^{a} \pm 2.46$ & $71.37^{a} \pm 4.66$ & $72.72^{\mathrm{a}} \pm 4.18$ & $6.96^{\mathrm{a}} \pm 0.43$ & $7.52^{\mathrm{a}} \pm 0,51$ & $7.26^{\mathrm{a}} \pm 1.08$ & $0.93 \pm 0.15$ & $0.94 \pm 0.17$ & $0.99 \pm 0.13$ \\
\hline Week 2 & $74.21^{\mathrm{a}} \pm 6.39$ & $72.10^{\mathrm{a}} \pm 4.4$ & $71.99^{\mathrm{a}} \pm 5.54$ & $6.41^{\mathrm{b}} \pm 0.51$ & $6.62^{b} \pm 1.14$ & $6.8^{\mathrm{a}} \pm 0.35$ & $0.65 \pm 0.01$ & $0.73 \pm 0.23$ & $0.66 \pm 0.16$ \\
\hline Week 3 & $69.71^{b} \pm 2.8$ & $71.87^{a} \pm 4.15$ & $74.05^{\mathrm{a}} \pm 6.89$ & $5.42^{\mathrm{b}} \pm 0.48$ & $4.78^{\mathrm{b}} \pm 1.6$ & $7.2^{\mathrm{a}} \pm 0.39$ & $0.96 \pm 0.31$ & $0.74 \pm 0.11$ & $0.96 \pm 0.31$ \\
\hline Week 4 & $67.08^{b} \pm 0.15$ & $67.06^{\mathrm{b}} \pm 3.32$ & $71.06^{\mathrm{a}} \pm 6.97$ & $5.11^{b} \pm 0.72$ & $5.4^{\mathrm{b}} \pm 0.24$ & $6.77^{\mathrm{a}} \pm 0.21$ & $0.92 \pm 0.28$ & $0.83 \pm 0.24$ & $0.92 \pm 0.28$ \\
\hline Week 5 & $65.44^{b} \pm 0.76$ & $66.03^{b} \pm 3.36$ & $71.04^{\mathrm{a}} \pm 8.2$ & $5.04^{\mathrm{b}} \pm 0.8$ & $5.18^{b} \pm 0.97$ & $6.77^{\mathrm{a}} \pm 0.4$ & $1.04 \pm 0.68$ & $0.96 \pm 0.33$ & $1 \pm 0.56$ \\
\hline Week 6 & $64.19^{b} \pm 1.79$ & $64.95^{\mathrm{b}} \pm 4.43$ & $70.53^{a} \pm 6.06$ & $4.66^{\mathrm{b}} \pm 1.17$ & $5.57^{b} \pm 0.66$ & $6.99^{\mathrm{a}} \pm 0.49$ & $0.8 \pm 0.11$ & $0.91 \pm 0.08$ & $0.88 \pm 0.16$ \\
\hline Week 7 & $65.2^{\mathrm{b}} \pm 1.58$ & $62.77^{\mathrm{b}} \pm 3.96$ & $69.73^{a} \pm 4.9$ & $4.86^{\mathrm{b}} \pm 0.79$ & $5.51^{b} \pm 0.19$ & $7^{\mathrm{a}} \pm 0.55$ & $1.04 \pm 0.08$ & $0.93 \pm 0.04$ & $1.01 \pm 0.08$ \\
\hline
\end{tabular}

For each analyzed characteristic: Means with the same letter -in each line and column- are not significantly different: $p \geq 0.05$

Weeks 6 and 7: After stopping drinking milk

Group 1: Diabetic dogs receiving $250 \mathrm{ml}$ raw camel milk / dog/ day

Group 4: Diabetic dogs getting $250 \mathrm{ml}$ pasteurized camel milk / dog/ day

Group 5: Diabetic dogs receiving $250 \mathrm{ml}$ boiled camel milk / dog/ day

Table 2: Effect of heat treatment on the weekly variations of total proteins, cholesterol and TG concentrations on diabetic dogs

$\mathrm{mmol} / \mathrm{l}$ ) from week 3 and on total proteins concentrations from week 4 $(74.84 \pm 5.45$ to $67.06 \pm 3.32 \mathrm{~g} / \mathrm{l})($ Table 2$)$.

A normal range of total proteins and cholesterol was investigated by the end of camel milk treatment and all dogs showed a clinically healthy state.

When receiving boiled camel milk, diabetic dogs did not show any improvement in proteins profile $(72.03 \pm 6.49 \mathrm{~g} / \mathrm{l})$ and the same result was illustrated in lipids profile by high cholesterol levels (about $7.02 \pm$ $0.44 \mathrm{mmol} / \mathrm{l})$ (Table 2).

\section{Discussion}

The efficacy of raw and pasteurized camel milk on glycemic control, and lipid and proteins profile was evaluated in this project using Alloxan-induced diabetic dogs.

A single dose of alloxan injected to dogs was able to produce a reproducible model of diabetes mellitus that had minimal beta cell activity, and elevated glucose, total proteins and cholesterol levels. Alloxan injection causes a toxic effect on kidney and liver in addition to the pancreas as investigated by other study on alloxan induceddiabetes in dogs [5].

Diabetes in dogs is generally associated, in addition to high blood glucose levels, with an increase of total proteins concentrations $[14,15]$ which was illustrated in our study in all dogs after injection of alloxan and especially in dogs from group 2 treated with cow milk during the trial $(82.83 \pm 3.83 \mathrm{~g} / \mathrm{l})$. This can be due to the toxicity of alloxan on the proximal straight renal tube as reported by Watanabe et al. [16].
A significant decrease on blood glucose levels was well showed on dogs treated with camel milk. This decrease was statistically illustrated since week 3 and associated to a decline of total proteins and cholesterol concentrations and a steadiness of this state since week 3 and after stopping to drink camel milk.

This hypoglycemic effect of camel milk may be due to the high level of insulin in comparison to cow milk [17], whereas in our assay, the results cannot be due to this particularity because the efficacy of camel milk on glycemic control was observed also after stopping to drink camel milk (group 1).

This therapeutic effect of camel milk was traditionally described and a good glycemic control or anabolic effect of this product was mentioned $[9,18]$. It may be explained by the particularity and properties of camel milk in comparison with milk from other species [19].

High mineral content on vitamin $\mathrm{C}$ intake may act as antioxidant there by removing free radicals, which may provide an additional benefit to the animals treated with camel milk [20]. It may be explained by the particularity and properties of camel milk in comparison with milk from other species, such as the absence of $\beta$-lactoglobulin, the high amount of polyunsaturated fatty acids (C18:1-C18: 3 ), and the high amount of vitamin B3 [21] and also some particularities of camel immunoglobulin, such as their small size and weight which offers enormous potential to camel milk. Also camel milk immunoglobulin, of relatively small size and weight, might offer an interplay with host cell protein leading to an induction of regulatory cells and finally leading to a downward regulation of immune system and $\beta$-cell salvage [22,23]. 
The therapeutic efficacy of camel milk on Alloxan-induced diabetic dogs was well shown in the first test (raw camel milk) and after pasteurization which explain that this treatment did not have any effect on the camel milk composition and the anti-diabetic property. Some previous study showed that there was no change on whey camel milk proteins when treated at same temperature $[24,25]$.

Except this effectiveness is sensitive to high temperature especially after boiling $\left(100^{\circ} \mathrm{C}\right)$; the active substance $(\mathrm{s})$ responsible on this effect may be sensitive to high temperature. El-Agamy, 2000 reported that after heating up to $100^{\circ} \mathrm{C}$ the effects were less on camel milk a-lactalbumin and Ig G compared with cow milk however a completely denaturation of camel lactoferrine was shown at this temperature.

Also some previous study $[26,27]$ reported that heat treatment of camel milk allowed to a demineralization of the caseins micelle and to an increase of soluble Ca concentrations.

\section{Conclusion}

From the results obtained it can be concluded that:

(a) Raw camel milk can be used as solution to treat alloxan induced diabetic dogs.

(b) This therapeutic property of camel milk was losing after treatment of camel at $100^{\circ} \mathrm{C}$ (boiled camel milk).

(c) Pasteurization can be used not only to store the camel milk but also to preserve this therapeutic particularity.

More study was actually warranted to identify the active principle responsible of this remedial property in camel milk.

\section{Acknowledgement}

We are thankful to Mr Barmat Ahmed and Mr Benbelgacem Hamed for their help in providing camel milk. We are also grateful to Dr. Barhoumi Kamel for his serious help during the experiment.

\section{References}

1. Huang SW, Maclaren NK (1976) Insulin-dependent diabetes: a disease of autoaggression. Science 192: 64-66.

2. Rerup CC (1970) Drugs producing diabetes through damage of the insulin secreting cells. Pharmacol Rev 22: 485-518.

3. Szkudelski T (2001) Mechanism of alloxan and streptozotocin action in beta cells of the rat pancreas. Physiol Res 50: 537-546.

4. Tyrberg B, Anderson A, Hakan Borg LA (2001) Species differences in susceptibility of transplanted and cultured pancreatic islets to the $\beta$-cell. Gen Comp Endocrinol 122: 238-251.

5. Kim JM, Chung JY, Lee SY, Choi EW, Kim MK, et al. (2006) Hypoglycemic effects of vanadium on alloxan monohydrate induced - diabetic dogs. J Vet Sci: 391-395.

6. Pari L, Amarnath SM (2004) Antidiabetic activity of Boerhaavia diffusa L.: Effect on hepatic key enzymes in experimental diabetes. J Ethnopharmacol 91: 109113

7. Lemhadri A, Zeggwagh NA, Maghrani M, Jouad H, Eddouks M (2004) Antihyperglycaemic activity of the aqueous extract of Origanum vulgare growing wild in Tafilalet region. J Ethnopharmacol 92: 251-256.

8. Prince PS, Kamalakkannan N, Menon VP (2004) Antidiabetic and antihyperlipidaemic effect of alcoholic Syzigium cumini seeds in alloxan induced diabetic albino rats. J Ethnopharmacol 91: 209-213.

9. Agrawal RP, Sahani MS, Tuteja FC, Ghouri SK, Sena DS, et al. (2005) Hypoglycemic Activity of Camel Milk in Chemically Pancreatectomized RatsAn Experimental Study. Int J Diab Dev Countries 25: 75-79.

10. Niwa M, Rashid S, Shum K, Mathoo JM, Chan O, et al. (2000) Effect of JTT-501 on Net Hepatic Glucose Balance and Peripheral Glucose Uptake in Alloxan induced diabetic dogs. Metabolism 49: 862-867.
11. Matsuhisa M, Shi ZQ, Wan C, Lekas M, Rodgers CD, et al. (1997) The effect of pioglitazone on hepatic glucose uptake measured with indirect and direct methods in alloxan - induced diabetic dogs. Diabetes 46: 224-231.

12. Farah Z (1996) Camel milk: Properties and products, 3rd edn. Swiss Centre for Development Cooperation in Technology and Management, StGallen, Switzerland

13. Association Française de Normalisation (1993) Contrôle de la qualité des produits alimentaires. Lait et produits laitiers, Afnor (Ed) Paris, France.

14. Siliart B, Garnier F (1995) Exploration des affections endocriniennes du chien et du chat. Point Vét 26: 761-770.

15. Toulon $M(1986)$ Le diabète sucré du chien, maladie chronique. Point Vét 17 681- 691.

16. Watanabe D, Nakara H, Yamaguchi Y, Akagi K, Hoshiya T, et al. (2004) The pathological features of alloxan diabetes in beagle dogs. J Toxicol Pathol 17 187-195.

17. Shehadeh N, Gelertner L, Blazer S, Perlman R, Solovachik L, et al. (2001) Importance of insulin content in infant diet: Suggestion for a new infant formula. Acta Paediatr 90: 93-95.

18. Agrawal PP, Swami SC, Beniwal R, Kochar DK, Sahani MS, et al. (2003) Effect of camel milk on glycemic control, risk factors and diabetes quality of life in type 1 diabetes: A randomized prospective controlled study. J Camel Practice and Research 10: 45-50.

19. Baumrucker CR, Errondu NE (2000) Insulin like growth factor (IGF) system in the bovine mammary gland and milk. J Mammary Gland Biol Neoplasia. 5 53-64.

20. Agrawal RP, Kochar DK, Sahani MS, Tuteja FC, Ghorui SK (2004) Hypoglycemic activity of camel milk in streptozotocin induced diabetic rats. In J Diab Dev Countries 24: 47-49.

21. Farah Z (1993) Composition and characteristics of camel milk. J Dairy Res 60 $603-626$

22. Hamers-Casterman C, Atarbouch T, Muyldermans S, Robinson G, Hamers C et al. (1993) Naturally occurring antibodies devoid of light chains. Nature 363 446-448.

23. Agrawal RP, Saran S, Sharma P, Gupta RP, Kochar DK, et al. (2007) Effect of camel milk on residual $\beta$-cell function in recent onset type 1 diabetes. Diabetes Res Clin Pract 77: 494-495.

24. Farah Z (1986) Effect of heat treatment on whey proteins of camel milk Milchwissenschaft 41: 763-765

25. Elagamy EI (2000) Effect of heat treatment on camel milk proteins with respect to antimicrobial factors: a comparison with cows' and buffalo milk proteins. Food Chemistry 68: 227-232.

26. Attia H, Kherouatou, N, Fakhfakh N, Khorchani T, Trigui N (2000) Dromedary milk fat: Biochemical, microscopic and rheological characteristics. J Food Lipids 7: 95-112.

27. Attia H, Kherouatou N, Ayadi A (2000) Acidification chimique directe du lait : Corrélation entre le matériel micellaire et les micro et macrostructures des laits acidifiés. Sc Aliments 20: 289-307. 